\title{
Down but Never Out! Narratives on Mental Health Challenges of Selected College Students During the COVID-19 Pandemic in the Philippines: God, Self, Anxiety, and Depression
}

\section{Dalmacito A. Cordero Jr ${ }^{1}(\mathbb{0}$}

Accepted: 29 November 2021 / Published online: 16 January 2022

(c) The Author(s), under exclusive licence to Springer Science+Business Media, LLC, part of Springer Nature 2021

\begin{abstract}
The COVID-19 pandemic is continuously causing serious effects on the mental health of college students due to the series of lockdowns and sudden shifting of faceto-face classes to fully online. The study aims to determine and explore the various themes that play a significant role in the development of this issue by an in-depth study of selected reflection papers submitted in class. These texts were interpreted and analyzed using interpretative phenomenological analysis. Findings revealed three major themes: anxiety and depression as serious effects of the pandemic, God/ Higher Being as the first and/or last source of support and, the essentiality of selfawareness and self-acceptance in improving mental health. These themes which are contextualized in nature hope to contribute to future research in formulating effective interventions and strategies in the war against the negative effects of the pandemic most especially for the welfare of college students.
\end{abstract}

Keywords COVID-19 pandemic · God/higher being · Mental health · Selfacceptance $\cdot$ Self-awareness $\cdot$ Support

\section{Introduction}

Lately, I've been having anxiety and depression due to the quantity of workload handed out to us with also the added weight of the pandemic. Since we're mobile in our own homes, it's easier for us to get into depression due to isolation. Being inside my room all day, doing all of the school works and

Dalmacito A. Cordero Jr

dalmacito.cordero@dlsu.edu.ph

1 Department of the Theology and Religious Education (DTRE), De La Salle University, Manila, Philippines 
requirements handed out to us with a lack of human contact and connections has taken a toll on me. I've been feeling so drained and burnt out like I cannot continue with this term anymore.

This excerpt from a student's reflection paper is a clear indication of her alarming situation during this COVID-19 pandemic. The devastating effects of this crisis post a grave concern to the overall well-being of everyone most especially to college students. These ushered many students into greater risks during the lockdowns and other restrictions imposed by various governments worldwide. Colleges and universities throughout the world were obliged to shift to pure online classes. The sudden change caused students to break the usual routines of socializing face-to-face with their classmates, teachers, and friends. Government mitigated preventive measures to stop the spread of the virus and ensure the safety of everyone but negative effects emerged among the people of the society. Numerous studies were recently conducted highlighting the negative impact of this tragedy to the mental health of college students.

An online survey using the Depression Anxiety Stress Scale (DASS-21) and Impact of Event Scale was conducted on 2530 members of the University of Valladolid in Spain. Findings revealed moderate to extremely severe scores of anxiety, depression, and stress by $21.34 \%, 34.19 \%$, and $28.14 \%$ of the respondents, respectively. A total of $50.43 \%$ of respondents presented moderate to severe impact of the outbreak. Students from Arts \& Humanities and Social Sciences \& Law showed higher scores related to anxiety, depression, stress, and impact of the event with students from Engineering \& Architecture (Odriozola-González et al., 2020). In Russia, Belarus, and Iran, the pandemic also caused various levels of fear, stress, and anxiety. Utilizing the Fear of COVID-19 Scale, 850 young adults from Russia and Belarus were able to complete the survey. The majority of participants were university students and graduates. Females, students, and others from Russia recorded higher levels of COVID-19-related fear than those from Belarus. Respondents from Russia and Belarus, on the other hand, showed less fear than people from Iran who were surveyed earlier (Reznik et al., 2020). In Switzerland, a total of 557 undergraduate students of Lucerne University of Applied Sciences and Arts took part in an online survey regarding the disruption caused by the pandemic. Of the responding students, $85.8 \%$ were reported to have experienced anxiety, for which the symptoms, in the majority of cases, can be classified as "mild". Women, too, had significantly higher mean anxiety scores when compared to men (Lischer et al., 2021).

In Bangladesh, 476 university students participated in a cross-sectional webbased survey on the effects of the pandemic. Findings revealed that the students were experiencing heightened depression and anxiety. Around $15 \%$ of the students reportedly had moderately severe depression, whereas $18.1 \%$ were severely suffering from anxiety (Islam et al., 2020). In India, the lockdown also caused various levels of anxiety to college students. With the use of Generalized Anxiety Disorder Scale (GAD-7) and Hamilton Anxiety Rating Scale (HAM-A) among 209 respondents, findings revealed that $1.44 \%$ had severe anxiety, $14.35 \%$ had moderately severe anxiety, $36.36 \%$ moderate anxiety, and $47.85 \%$ had mild anxiety (Biswas \& Biswas, 2021). In China, 7,143 responses were obtained utilizing cluster sampling from 
Table 1 Spring 2020 College Student Survey Infographic Report on Mental Health

\begin{tabular}{|c|c|}
\hline Findings on some aspects of mental health & Statistics \\
\hline Students with a mental health problem & $\begin{array}{l}\text { - } 20 \% \text { of college students say their mental health has } \\
\text { significantly worsened under COVID-19 }\end{array}$ \\
\hline $\begin{array}{l}\text { Students who reported the negative impact of the } \\
\text { pandemic on their mental health }\end{array}$ & $\begin{array}{l}\text { - } 80 \% \text { of college students report that COVID-19 has } \\
\text { negatively impacted their mental health }\end{array}$ \\
\hline $\begin{array}{l}\text { The most common ways that COVID-19 has } \\
\text { impacted students' lives }\end{array}$ & $\begin{array}{l}\text { - } 91 \% \text { stress or anxiety } \\
\text { - } 81 \% \text { disappointment or sadness } \\
\text { - } 80 \% \text { loneliness or isolation } \\
\text { - } 48 \% \text { financial setback } \\
\text { - } 56 \% \text { relocation }\end{array}$ \\
\hline Self-care has been challenging for students & $\begin{array}{l}\text { - } 76 \% \text { have trouble maintaining a routine } \\
\text { - } 73 \% \text { struggle to get enough physical activity } \\
\text { - } 63 \% \text { find it challenging to stay connected with } \\
\text { others }\end{array}$ \\
\hline Spending time together & $\begin{array}{l}\text { - } 85 \% \text { say that focusing on schoolwork despite } \\
\text { distractions has been the most difficult thing about } \\
\text { the stay-at-home order } \\
\text { - More than talking, especially about COVID-19, } \\
\text { students say that the \#1 way parents can support } \\
\text { them is simply spending time with them }\end{array}$ \\
\hline Resource needs & $\begin{array}{l}\text { - More than half of students (55\%) say that they } \\
\text { would not know where to go if they or someone } \\
\text { they knew needed professional mental health } \\
\text { services right away } \\
\text { - Students are finding tools that promote social } \\
\text { connection most helpful for caring for their mental } \\
\text { health. These include video calls, digital social } \\
\text { gatherings (i.e. games or Netflix watch parties), } \\
\text { phone calls, and in-person conversations }\end{array}$ \\
\hline The hopefulness of students despite the pandemic & $\begin{array}{l}\text { - } 79 \% \text { of college students feel hopeful about achiev- } \\
\text { ing their school-related goals and their future job } \\
\text { prospects }\end{array}$ \\
\hline
\end{tabular}

college students of Changzhi Medical College. The findings indicated that $0.9 \%$ of the respondents were experiencing severe anxiety, $2.7 \%$ moderate anxiety, and $21.3 \%$ mild anxiety. In addition, living in urban areas, family income stability, and living with parents were protective factors against anxiety while having relatives or acquaintances infected with COVID-19 was a risk factor for increasing the anxiety of college students (Cao et al., 2020).

Active Minds (2020), a premier nonprofit organization supporting mental health awareness and education for young adults in the United States, surveyed 2,086 college students regarding the impact of COVID-19 on their mental health. The synthesized report of their findings is presented in Table 1:

Table 1 illustrates the significant impact of the COVID-19 pandemic on the students' mental health. The crisis presented many challenges not only to students but also to their parents and teachers, since they are the ones who are usually in direct 
contact with them, whether face-to-face or virtually. Having a healthy family environment led by parents is very important in managing the mental health of students. Since these teens usually look up to their parents as role models, there is a greater chance of imbibing their positive attitude in handling distress. Siblings too, provide an added support to the student. There are times where the student is more confident in expressing concerns to a sibling. There are concerns among siblings that they find awkward to share with their parents. Having a harmonious relationship within the family helps lighten a confused mind.

Teachers, on the other hand, also play a critical role in the promotion of psychological well-being among the students. In recent research, the authors summarized these educators' roles as to:

(1) devote some time related to educating about COVID-19 and preventive health behavior by using the guidelines of the international organizations, according to the maturity level of the students; (2) conduct creative online academic and non-academic sessions by making their classes more interactive; (3) promote mental health among students by discussing what well-being is and how it is important for students; (4) make students understand the importance of prosocial behavior and the importance of virtues like empathy and patience among others; (5) interact with parents online or by phone regarding feedback about students and their mental health; (6) serve as a doorway for identification and referral to specialty mental health providers; (7) make arrangements to ensure that the reading material related to academics and life skills are made available to the underprivileged students who do not have access to the internet. (Singh et al., 2020).

Also, the Counseling and Psychological Services of the University of Michigan summarized the impact of the pandemic on the mental health of college students:

It is well studied that college students are especially prone to feelings of loneliness, and they experience higher rates of anxiety and depression compared to the general population. During this period of social isolation, uncertainty, and abrupt transitions, they are prone to further worsening of these feelings. Removal from their social support system and extracurricular activities at their school can cause students to feel less connected with their friends, organizations, and hobbies. Besides, they are facing uncertainty about their future, their health, and the health of their friends and loved ones. The situation they are living through is stressful and anxiety-provoking, as there is a constant fear of the unknown in addition to a loss of control, making them especially vulnerable to developing mental health concerns. (Michigan Medicine, 2021).

In the Philippines, college students are also experiencing similar challenges brought about by the pandemic. A study was conducted on 1,879 respondents during the early phase of the outbreak in the country. Findings showed $16.3 \%$ rated the psychological impact from moderate-to-severe; $16.9 \%$ reported moderate-to-severe depressive symptoms; $28.8 \%$ had moderate to severe anxiety levels; and $13.4 \%$ had moderate-to-severe stress levels (Tee et al., 2020). In another study, 243 respondents 
from different colleges and universities in Western Samar, Philippines completed an online survey. Standardized scales were used to gather data including the Lockdown Fatigue Scale (LFS), Brief Resilience Scale, Coping Behaviors Questionnaire, and a single-item measure of general health. The research concluded that college students experienced moderate levels of fatigue during the mandatory lockdown or home confinement period. Resilient students and those who perceive higher social support experienced lower levels of fatigue during the lockdown period compared to students with low resilience and social support (Labrague \& Ballad, 2020).

The pandemic had also affected nursing students in the country. In cross-sectional research conducted on 345 students of a government-funded nursing school, findings revealed that the pandemic had a significant moderate impact on the Quality of Life (QoL) of the respondents concerning psychological resilience (Guillasper et al., 2021). A related cross-cultural study was also conducted comparing the Filipinos' and Chinese's physical and mental health during the pandemic. The responses from the 849 Filipinos indicated significantly higher levels of depression, anxiety and stress than that among the Chinese respondents. Filipino respondents were more likely than the Chinese to report physical symptoms resembling COVID-19 infection, recent use of medical services with lower confidence, recent direct and indirect contact with COVID-19, concerns about family members contracting COVID-19, and dissatisfaction with health information (Wang et al., 2020).

These sample studies utilized mainly quantitative methods of analysis and presented numerical data which are obtained via online/web-based surveys. While this research explores the same theme - on the effects of the pandemic on the mental health of Filipino college students, the data were however individualized, since they were taken directly from the personal narratives of the participants through their submitted reflection papers in class. These data were then analyzed qualitatively to obtain themes that are essential in achieving the objective of this research. Thus, this paper aims to discover, in-depth, some basic realities regarding the effects of the pandemic on the various aspects of mental health of Filipino college students. With the explored contextualized themes, appropriate interventions can be formulated for future research which can be beneficial in addressing related issues.

\section{Method}

The researcher was persuaded to embark on this research because of the recurrent similar content of the reflection papers that were submitted by the students during the online class. I was tasked to handle four sections of Encountering the Word in the World (LCENWRD). It is an undergraduate general course offering in Theology that is focused on the Sacred Scripture. Since these students are studying in a Catholic university, they are required to take theology subjects regardless of whatever bachelor's degree they are pursuing. There were 179 college students enrolled in these sections for the second term of the academic year 2020-2021, with the age range of 19-22 years old. The variables in this research study consist of four demographic characteristics: gender, age, nationality, and religion. Table 2 presents the basic demographic profile of the participants. 
Table 2 Participants' demographic details

\begin{tabular}{lllll}
\hline Participant & Gender & Age & Nationality & Religion \\
\hline Participant \#1 & Male & 19 & Filipino & Roman catholic \\
Participant \#2 & Female & 20 & Filipino & Roman catholic \\
Participant \#3 & Male & 22 & Filipino & Roman catholic \\
Participant \#4 & Female & 20 & Filipino & Roman catholic \\
Participant \#5 & Female & 21 & Filipino & Roman catholic \\
Participant \#6 & Male & 21 & Filipino & Agnostic \\
\hline
\end{tabular}

One of the requirements of the course is to submit meaningful reflections regarding a specific topic. In this regard, I gave my students the task of writing a reflection regarding their most unforgettable faith experience in life. The experience may be a situation wherein they felt pressured or challenged about any aspects of their life. It was not surprising that the majority of them pointed out COVID-19 pandemic as one of the common challenges that they have experienced with the big adjustment of totally shifting from face-to-face classes to online setup. However, what was more striking, was that 41 of these 179 students (23\%) highlighted on their reflection papers the effect of the pandemic on their mental health.

This study is a qualitative type of research with an in-depth analysis of reflection papers to obtain the desired result. It utilizes one of the popular data analysis tools in qualitative psychology which is the Interpretative Phenomenological Analysis (IPA). The IPA was popularized by Jonathan Smith and it aims to provide detailed examinations of personal lived experience and produces an account of this experience in its own terms rather than any prescribed by the pre-existing theoretical preconceptions (Smith \& Osborn, 2015). IPA gives researchers the best opportunity to understand the innermost deliberation of the experiences of research participants. In short, it is participant oriented since it allows the participants to express themselves and their "lived experience" stories the way they see them without any distortion and/or prosecution (Alase, 2017). In traditional phenomenological studies, Coyle (2014) suggested that the average sample size between one and 12 is acceptable. This implies that the lesser number of participants is needed for a concentration on the data of experience. Other researchers recommended that six to eight participants are appropriate for an IPA study, as this size allows examining similarities and differences between individuals. For this study, the researcher has chosen six out of the 41 reflection papers as the sample size. Again, it is important to take note that these reflection papers were chosen from the total sample since they have similar themes, which is, pointing to the pandemic as the cause of the participants' mental health problems. In an IPA approach, six as the sample size is sufficient to represent the total population of this study.

To present how the IPA as an analysis tool is applied, the four basic stages nominated by Pietkiewicz and Smith (2014), which can be adapted by researchers, are described in Table 3. 
Table 3 Basic Guidelines of IPA and Brief Descriptions

Stages of Interpretative Phenomenological Analy- Brief Descriptions sis (IPA)

Stage 1: Multiple reading and making notes

Stage 2: Transforming notes into Emergent Themes

Stage 3: Seeking relationships and clustering themes

Stage 4: Writing a narrative account of the study
Close reading of the transcript several times to immerse in the data; Making notes about one's observations and reflections about the interview experience or any other thoughts and comments of potential significance; Highlighting distinctive phrases and emotional responses

Reflecting on the source material to transform notes into emerging themes; Formulating a concise phrase (themes) at a slightly higher level of abstraction which may refer to a more psychological conceptualization

Looking for connections between emerging themes, grouping them according to conceptual similarities, and providing each cluster with a descriptive label; Dropping of 'unfit' themes; Listing of major themes and subthemes, and relevant short extracts from the transcript

Taking the themes identified in the final table and writing them up one by one; Describing each theme and exemplifying it with extracts from interview, followed by analytic comments from the author/s

This research utilized all the IPA stages. It followed the first three stages of the tool while the fourth stage was integrated into the Results and Discussion section where the clustered themes were described and discussed thoroughly.

\section{Ethical Considerations}

All procedures performed in this study involving human participants were guided by standard institutional research ethics involving the category of Human Participants. Informed consent was included in the online platform, communicated to the participants, and discussed thoroughly with them at the start of the term. The consent form authorizes the researcher to use, if needed, all reflection papers and discussion entries, both hard and electronic copies, strictly for research purposes. It also states that nothing in the consent form is intended to replace any applicable laws. Furthermore, participants have been assured that any personal information, like real names and other personal data would be kept private and confidential. Participants who did not agree to the consent agreement had the right to request the researcher, at any point in time, to not include any of his/her course output. 


\section{Results and Discussion}

The table in the Appendix presents the results of the data analysis using the IPA as a tool. As mentioned, six reflection papers were being analyzed and all these samples emphasized the significant effect of the pandemic on college students' mental health. The first column shows an excerpt from the original reflection paper with some highlighted selected words/phrases implying that these were of greater significance. Before highlighting these words, it is important to note that these excerpts were read multiple times for familiarity. The second column contains the exploratory notes and comments. This is where relevant insights and thoughts are formed to describe the highlighted words. Emerging themes are found in the third column. These themes are words/phrases that express what the notes/comments represent in general. The last column, then, is the synthesis of what the whole reflection is trying to drive at by clustering the emerging themes into major and minor themes. Nonrelevant themes were excluded. These major themes then will be described comprehensively and used as the focus of discussion, since they were identified as the most significant thoughts that were drawn from the research. (See Appendix for the synthesized data analysis using IPA).

The IPA resulted in three major themes being extracted from the reflection papers. It is important to note that the minor themes were also important in the analysis since they greatly contributed to tracing the overall picture of the participants' experience. However, the major themes epitomize the concrete realities that describe the issue as well as the situation of the participants. The major themes include: anxiety and depression as serious effects of the pandemic; God/Higher Being as the first and/or last source of support; and, the essentiality of self-awareness and selfacceptance in improving mental health.

\section{Anxiety and Depression: Serious Effects of the Pandemic}

I was alone and desperate. I had nobody to contact. I didn't reach out to my family and friends. I didn't want to burden my parents with problems and disappoint them with failures... My stress and desperation accumulated to what I thought was insurmountable. I began avoiding people. Despite everything,

I always do one thing to allay my fears and anxieties that drove me to mental breakdowns... - Participant \#4.

The COVID-19 pandemic can cause mental health problems such as anxiety and depression which are considered forms of human suffering (Cordero, 2021b). This is what Participant \#4 has experienced the first time when lockdowns and other restrictions were imposed because of the pandemic. At first, these initial restrictions by the government will simply result in the ordinary feeling of boredom that can be managed easily - since it will only be temporary. One can deal with it by diverting one's attention to other home activities such as cooking, playing computer games, learning to play musical instruments, doing gardening, and acting like plantito and plantita, and many others. But as the lockdown was extended into long weeks, then 
lasted for months, and even for almost two years now, the negative effects on mental health became more serious and difficult to address.

Anxiety and depressive disorders are among the most common psychiatric illnesses; they are highly comorbid with each other, and together they are considered to belong to the broader category of internalizing disorders (Kalin, 2020). Anxiety is an "apprehensive anticipation of future danger or misfortune accompanied by a feeling of dysphoria or somatic symptoms of tension" (American Psychiatric Association, 2000, p. 820). It is derived from the word "to vex or trouble" which is commonly associated with feelings of fear, worry, discomfort, and dread (Antony \& Barlow, 1996). Depression, on the other hand, is a state of disinterest in daily activities. It is surmised that people facing a pandemic with no vaccination would result in fear of the unknown making them anxious, stressed, and depressed (Rehman et al., 2020). Studies demonstrate that anxiety disorders generally lead to major depressive disorders (Kessler \& Wang, 2008). In another study conducted on 255 depressed adult outpatients, comorbid anxiety disorder diagnoses were present in $50.6 \%$ of these patients and included social phobia (27.0\%), simple phobia (16.9\%), panic disorder (14.5\%), generalized anxiety disorder (10.6\%), obsessive-compulsive disorder (6.3\%), and agoraphobia (5.5\%). Both social phobia and generalized anxiety preceded the first episode of major depression in $65 \%$ and $63 \%$ of cases, respectively, panic disorder (21.6\%) and agoraphobia (14.3\%) were much less likely to precede the first episode of major depression than to emerge subsequently (Fava et al., 2000). These studies show the critical association between anxiety and depression.

During this pandemic, some college students were struggling to cope up with the demands of academic requirements most especially when the setup was shifted fully to online. There are several reasons why some students cannot perform well in a fully online class - adaptation difficulty to the online classroom as a new environment; technical issues like low internet speed/outages and crashes; poor time management; lack of human contact; too many and complicated requirements; poor support services, and many others. The college level is the opportune time to make a decisive move as a final preparation for landing a good job for one's future. Achieving a high level of mastery for the chosen academic degree is a must. One major complaint of students is the volume of requirements that must be accomplished given the unreasonable deadlines set amidst the unfortunate situation they are experiencing. Thus, this aggravates their level of anxiety. In a related study, the results revealed that spending six hours or more a day watching TV or using computers was associated with a higher risk for depression (Madhav et al., 2017). For young people who spend seven hours or more a day on computer screens are more than twice as likely to be diagnosed with depression or anxiety than those who use screens for an hour a day only (Twenge \& Campbell, 2018). What even adds to these woes is the pressure coming from some parents who expect outstanding performance from their children.

Depression in college students also became prevalent. during this pandemic. In a nationwide survey conducted on 33,000 college students in the United States, one of the key findings revealed that $39 \%$ are suffering from moderate to major depression (Eisenberg et al., 2020). One common determinant that triggers depression is the lack of social support. Social support refers to the student's network of friends, 
acquaintances, and mentors to turn to, especially in times of need or crisis which positively influences academic performance, benefits overall wellbeing, and eases the anxiety many students face as they transition from life as a high schooler to college (Affordable Colleges Online, 2021). The suspension of physical/face-to-face communication of students with their classmates, friends, and professors greatly lessened this much needed support. While family support is essential in this situation, not all students can reveal their present condition to their parents because of either consideration/care or fear of the consequence. Some parents are in financial crisis and even jobless because of the pandemic, so they have to find a solution to augment the situation. As Participant \#4 mentioned, "I did not want to burden my parents with problems and disappoint them with failures..." For those from affluent families, some students are afraid that if they reveal what is going on with them in terms of poor academic performance, they will be grounded or at worst, forced to stop schooling.

Anxiety and depression are serious mental health problems that are caused by the pandemic. Son et al. (2020) firmly posited that these mental health issues are considered as the leading impediment to academic success. It is also important to note that mental illness can affect students' motivation, concentration, and social interactions-crucial factors for students to succeed in higher education (Unger, 2007). If the students are suffering from anxiety and depression, they may not have enough capability to perform well academically. Thus, they may not graduate from their chosen degree courses with flying colors. More importantly, this condition may seriously affect their overall well-being.

\section{God/Higher Being as the First and/or Last Source of Support}

I decided to talk to God and ask for guidance: what to do, how can I cope, how to ease the burden, etc. Through these, I realized that opening up to someone somehow lessens the burden in your heart. God was always with me from the beginning. Even before the pandemic, God has always been by my side quietly looking out for me and listening to my problems; and I know that He has guided me and has been listening to my concerns... From the start of this year, 2021, my mental health is slowly becoming stable again... For that, I thank God for helping me through my toughest times and has been with me whenever I needed someone to open up and talk to. More importantly, I thank God for the guidance He has provided me and answered my prayers. - Participant \#1.

Participant \#1 stressed the role of God in her life during the pandemic. Having experienced big challenges such as stress from academics, pressure from family's high expectations to excel in the chosen academic degree, disconnection from friends, worry for the family getting infected with the virus - all these were handled accordingly with the support and guidance of God through prayer. Though the pandemic's end is uncertain, she already claimed with confidence that everything will be fine since God will always guide her at all times. In fact, out of the 41 reflection papers that were selected for this study, 38 or almost $92 \%$ pointed out the significant 
role of God or any higher being as the source of support and guidance during this pandemic.

When catastrophe strikes, many people seek closeness to God. Prayer is a common way of dealing with adversity and it is one strategy for doing so (Dein et al., 2020). The COVID-19 pandemic inspired members of religious groups to find alternate ways of nurturing connectedness to their relevant God/higher being. Many churches, temples, synagogues, mosques, and other worshipping sites have closed down due to lockdowns and safety restrictions and protocols. Religious leaders and adherents find creative ways to organize their respective practices and rituals-performances and sermons on various social media platforms without sacrificing public health and still following government protocols. The Roman Catholic Church has begun live streaming the Pope's daily mass and Sunday sermon. A live stream of service at the National Cathedral in Washington, DC, drew more than twenty-five thousand viewers (Robinson, 2020). One priest in Maryland set up a drive-through confession, careful to keep a six-foot distance between himself and those who visit. Some Orthodox Jewish communities are bending their traditional rules and allowing minyanim (ritual prayer groups) to gather over Zoom (Heilweil, 2020). For Muslims, the closure of mosques does not mean that they will stop daily prayers communally. Individual prayers and worship in Islam play a greater role than communal ones. Muslims can pray five times a day wherever they are. Oftentimes, the home is the place where most praying takes place. In Hinduism, celebrations and prayers are home-bound events and if there is group worship, it is also live-streamed. Some temple priests in Uttar Pradesh said that they have declined requests to visit homes, suggesting instead that people should donate the money they would have spent cooking food to the chief minister's virus relief fund (Banerjee \& Fields, 2020). In Buddhism, the Dalai Lama (spiritual leader of the Tibetan people), other senior monks, and Buddhist organizations in Asia and worldwide have emphasized that this pandemic calls for meditation, compassion, generosity, and gratitude. They offer prayers and protective rituals known as apotropaics (magical protection rites) to protect against disease. These are meaningful ways to confront the anxieties of the global coronavirus pandemic, providing comfort and relief (Salguero, 2020).

In the Philippines, where $81 \%$ of its 110 million population are Roman Catholics, the belief in God has a significant role most especially during times of crisis. This is why even during the pandemic, Filipinos find creative ways for religious practices. Catholic congregations have taken steps to provide the public with online-based Church masses, community prayers, spiritual recollections and retreats, and eucharistic adoration and processions. People dealing with issues about mortality, coping and recovery are provided with online formative counseling and pastoral guidance. Many netizens have been moved and encouraged to signify support, some have shared the hashtag \#ChurchInAction on social media which can ease the impact of the current crisis (Del Castillo et al., 2020). Another alternative form of doing celebration is bringing it to the local parish instead of the big gathering in one place. This was done during the feast of the Black Nazarene where the priests in-charge just localized the celebration by bringing the sacred statue to various churches particularly in Manila and nearby cities (Cordero, 2021c). These creative faith-based 
practices/prayer rituals amid the pandemic are manifestations of how people acknowledge God as a significant source of guidance and support.

Concerning mental health problems, the American Psychological Association (2020) points out that many researchers consider religion and belief, which covers the belief in God or any higher being, can help people cope with mental distress during the pandemic in three ways:

(1) Encouraging them to reframe events through a hopeful lens. Positive religious reframing can help people transcend stressful times by enabling them to see a tragedy as an opportunity to grow closer to a higher power or to improve their lives; (2) Fostering a sense of connectedness. Some people see religion as making them part of something larger than themselves. This can happen through prayer or meditation, or through taking part in religious meetings, listening to spiritual music, or even walking outside; (3) Cultivating connection through rituals. Religious rituals and rites of passage can help people acknowledge that something momentous is taking place. These events often mark the beginning of something, as is the case with weddings, or the end of something, as is the case with funerals. They help guide and sustain people through life's most difficult transitions.

Suffering in this time of the pandemic moves us to find any source of support. Various major religions proclaim the presence of God or any higher being in one's life as the provider of this needed support. God assures us of this promise as what the bible states, "Do not fear, for I am with you; Do not be afraid, for I am your God. I will strengthen you, I will also help you, I will also uphold you with My righteous right hand" (Isa. 41:10). The experience of suffering gives us the chance to go back and rediscover our good nature since we are created by a good God. We are capable of transcending the painful effects of suffering because God created us as such and God never desires that we will be separated from that goodness (Cordero, 2021a). Lifting to God even our suffering, through prayer, can lighten the burden in one's mind and heart from the negative effects of the pandemic.

\section{Essentiality of Self-Awareness and Self-Acceptance in Improving Mental Health}

I started having the courage to acknowledge the situation and one step at a time, I started to open up to myself and others. I started accepting myself, recognizing my new strengths and weaknesses, working on myself. I also dared to fight against the sadness and day by day, I'm getting better at completing tasks and reconnecting with my friends. I was really glad when the time came that I no longer resent waking up in the morning. Although I didn't go back to my old self, I'm still proud of the current version of myself and I'm thankful for that moment that pushed me to end my suffering and allowed me to regain at least some parts of myself. - Participant \#6

This excerpt from the reflection of Participant \#6 relayed the initial steps that are essential in improving one's mental health amid the pandemic. Recalling his story, his mental health started to dwindle, and he became more anxious when the cases 
of those infected with COVID-19 was surging. Unprepared for the situation, he admitted that everything inside his head was completely a mess and his productivity was almost non-existent. This was because he was not aware of what he could do to address it given the fact that it was a "first time". Every time he encountered a difficult situation before, he just ran to his friends for support and this was done through face-to-face bonding. However, this response was not possible anymore because of the lockdown. Months passed by and he was feeling very heavy hearted. He could not function as well as he used to; his appetite was lost, he felt tremendous pressure meeting deadlines, he hated waking up every single day to face the same battle. He felt the need to look for support from a higher being-even though he is not affiliated to any religion. He also realized that connecting with friends virtually, although it may be less exciting, could still be helpful as being with them physically. In short, being aware of what he could do, recognizing his weaknesses and limitations, and accepting the current crisis, helped him to regain a healthy mind.

During this pandemic, many people were filled with mixed emotions that overwhelm them. Some try to cope with the unfortunate circumstances that come their way-making ends meet financially, being fed up with voluminous requirements in school, coping with the effects of the virus, grieving for the death of loved ones, and worrying about the unexpected tomorrow. On the other hand, others try to look at the positive perspective. They allot more quality time with their family, thus, strengthening family ties; discover and develop their hidden talents and skills; enjoy a lesser polluted environment brought by the lockdown. The complexity of oneself can prompt us to have that longing to discover more, especially when opportunity arises. Self-awareness is an inwardly focused evaluative process in which individuals make self/standard comparisons with the goal of better self-knowledge and improvement (Ashley \& Reiter-Palmon, 2012). In this paper, it is considered as the first step towards fulfilling the goal of achieving mental health. The role of self-awareness is paying attention to one's feelings, thoughts, and behaviors, for the identification of goal-related obstacles (Kreibich et al., 2020). It has long been seen by practitioners and researchers as both a primary means of alleviating psychological distress and the path of self-development for psychologically healthy individuals (Sutton, 2016). After having evaluated ourselves, we have an idea of whether what we are thinking, feeling, and acting are following standards and values. This is referred to as comparing against our standards of correctness (Ackerman, 2021). This, then, leads us to accept ourselves and decide to improve more to achieve a healthy mind.

Self-acceptance, on the other hand, is pointed out as the next step after the process of self-awareness. It is considered the foundation of mental health and wellbeing. It is acknowledging that we are complex, imperfect human beings who are not only capable of achieving accomplishments but also committing mistakes. We possess a realistic awareness of our strengths and weaknesses and accept ourselves despite our imperfections and uniqueness (Bernard, 2020). Having known and paid attention to one's character, an individual needs to accept whatever realities are present in one's self. These realities may include both positive and negative tendencies or qualities of behavior. The majority of the participants in this study claimed that they were able to regain their mental health because they have decided to embrace not only the current unfortunate situation but also their initial inappropriate attitudes 
towards it. They acknowledged in their reflections that some of them were weak in coping with pressure, too sensitive to feedbacks from others, complained a lot about assigned tasks, low self-esteem, and many others. Given these limitations, they have learned to accept and deal with the situation gradually, as the lockdown is continuously prolonged. In another related study, self-acceptance also became the initial step towards recovering from a mental issue caused by the pandemic. The author narrates:

... Since suffering is an unavoidable part of human affairs, the attitude of "acceptance" became my initial step. I realize that I cannot move on towards my recovery if in the first place I cannot accept the fact that I am facing a real mental issue. The numerous sleepless nights, sweating while the air conditioning system is on, speedy heartbeat rate, always feeling afraid of contracting the virus, and many other unusual experiences validate that indeed I am suffering from a mental problem. Accepting my condition does not mean I will remain helpless and not try anything to overcome it. (Cordero, 2021b)

The connection between self-awareness and self-acceptance is established. Self-awareness is the ability to recognize both personal strengths and weaknesses. Self-acceptance, on the other hand, paves the way to improve one's mental health by welcoming these entities without reservations. Research suggests that when we see ourselves clearly, we are more confident and more creative. We make sounder decisions, build stronger relationships, and communicate more effectively (Eurich, 2018). Having these abilities enable us to move forward despite having faced big challenges even for future ones since these serve as our "confidence boosters" toward the actualization of our plans. 


\section{Limitations of the Study}

This study focused on the mental health problems of the participants, specifically anxiety and depression, which were likely caused by the pandemic. In particular, the series of lockdowns and other restrictions by the government caused a lot of difficulties in terms of student academic performance and their behavior. There may be other causes of participants' mental health problems which were not included in this research such as bereavement, since some of their relatives/friends have died, or fear of getting infected with the virus, the poor financial standing of the family, and other issues. It is suggested that future studies dwell on these factors.

\section{Conclusion}

The COVID-19 pandemic has continuously caused serious effects on the overall well-being of college students worldwide. A greater effect is identified on their mental health as expressed in their reflections. The significant themes that were determined, such as anxiety and depression as serious effects of the pandemic were: God/ Higher Being as the first and/or last source of support, and, the essentiality of selfawareness and self-acceptance in improving mental health-which provide important implications for future research in the aspects of intervention and prevention from such catastrophe. These findings can assist in formulating effective strategies for battling the negative effects of the pandemic since these originated directly from the personal perspectives and in-depth experiences of college students. 


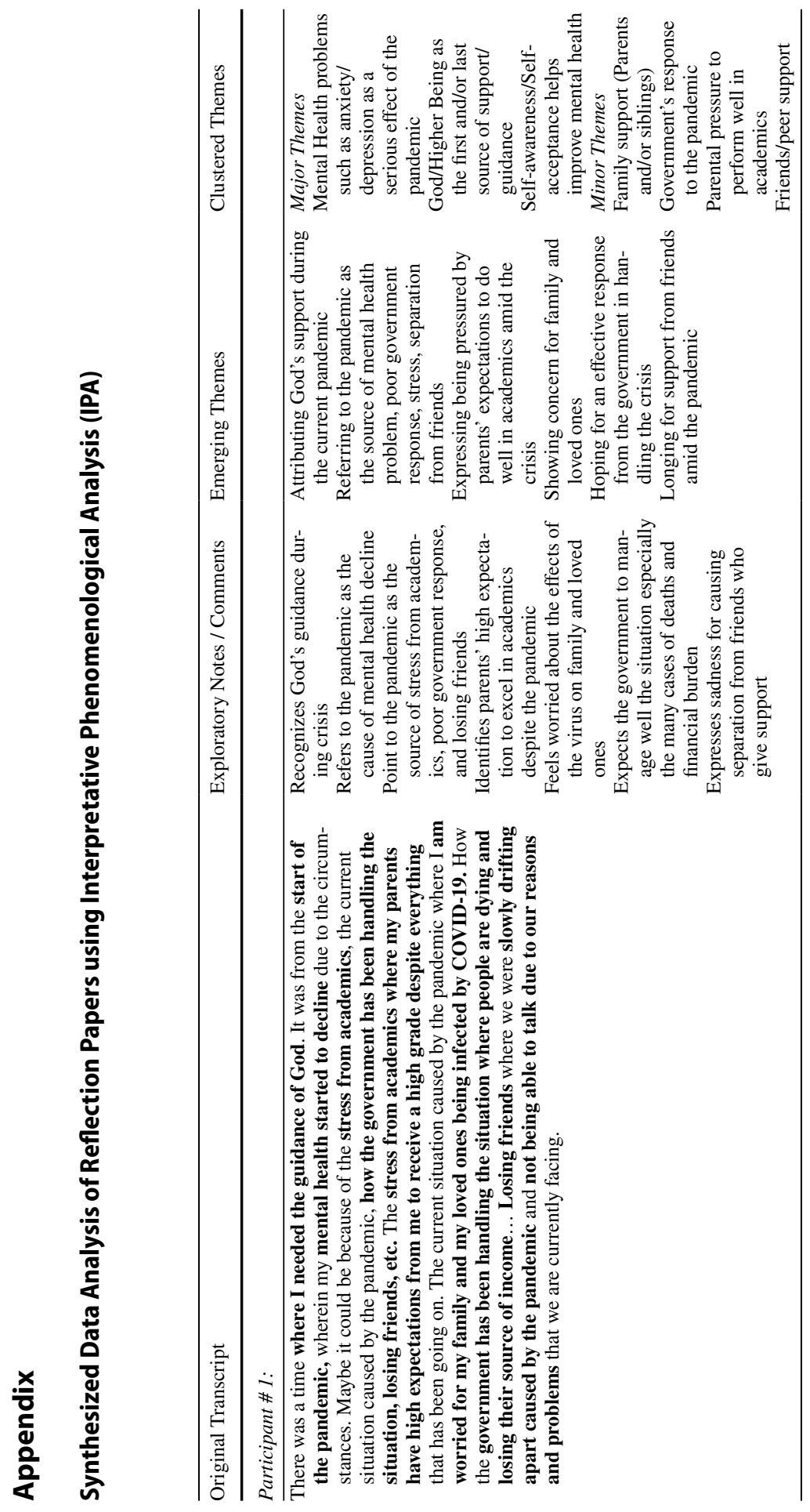




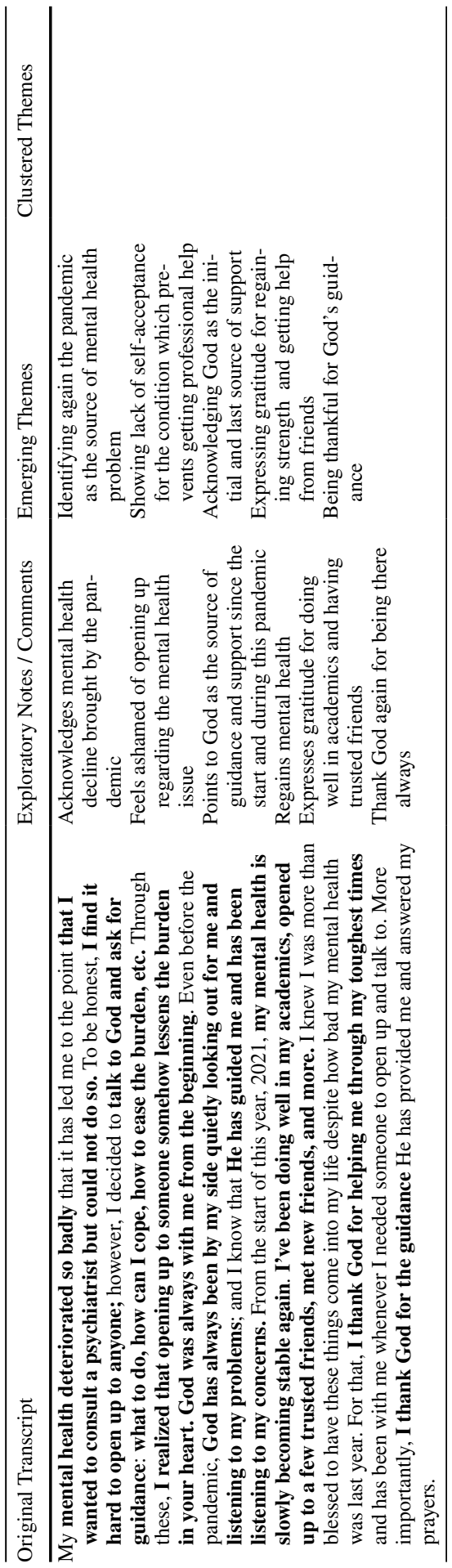




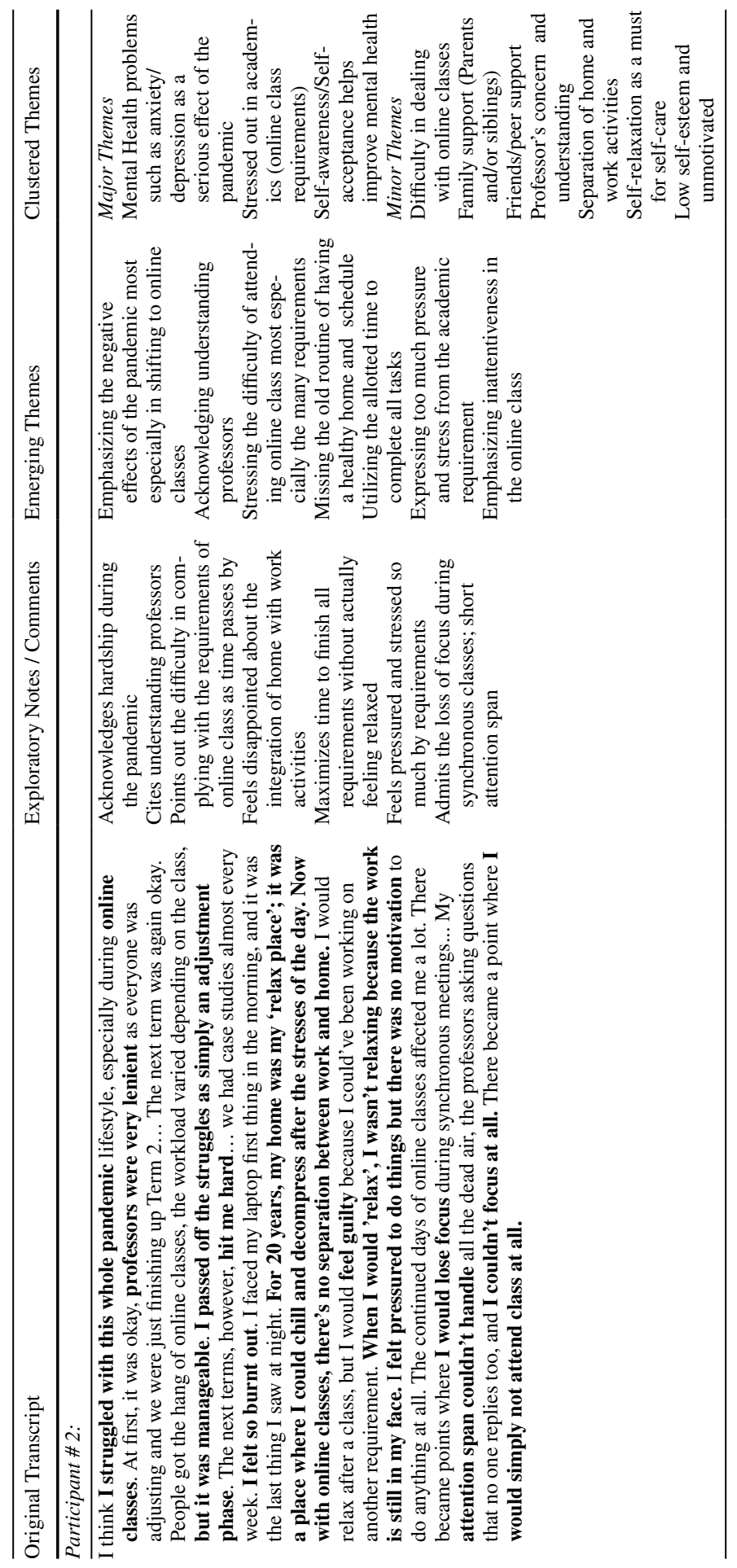




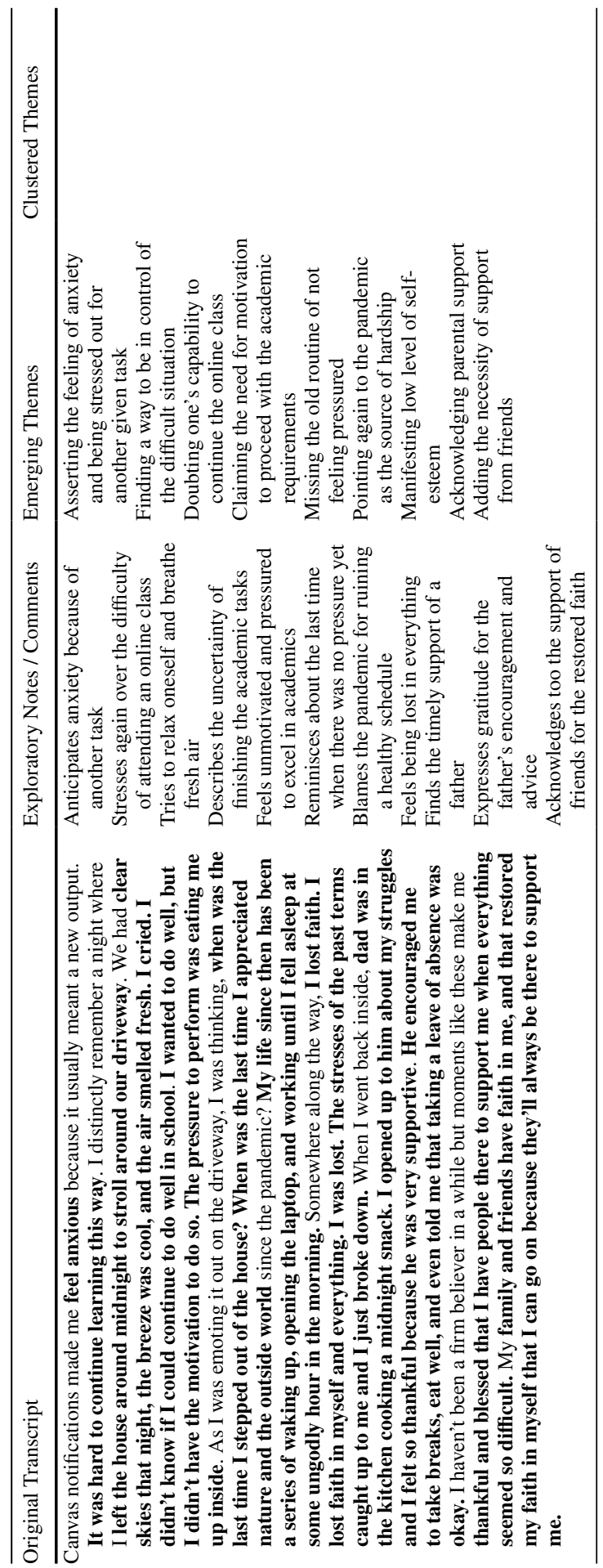




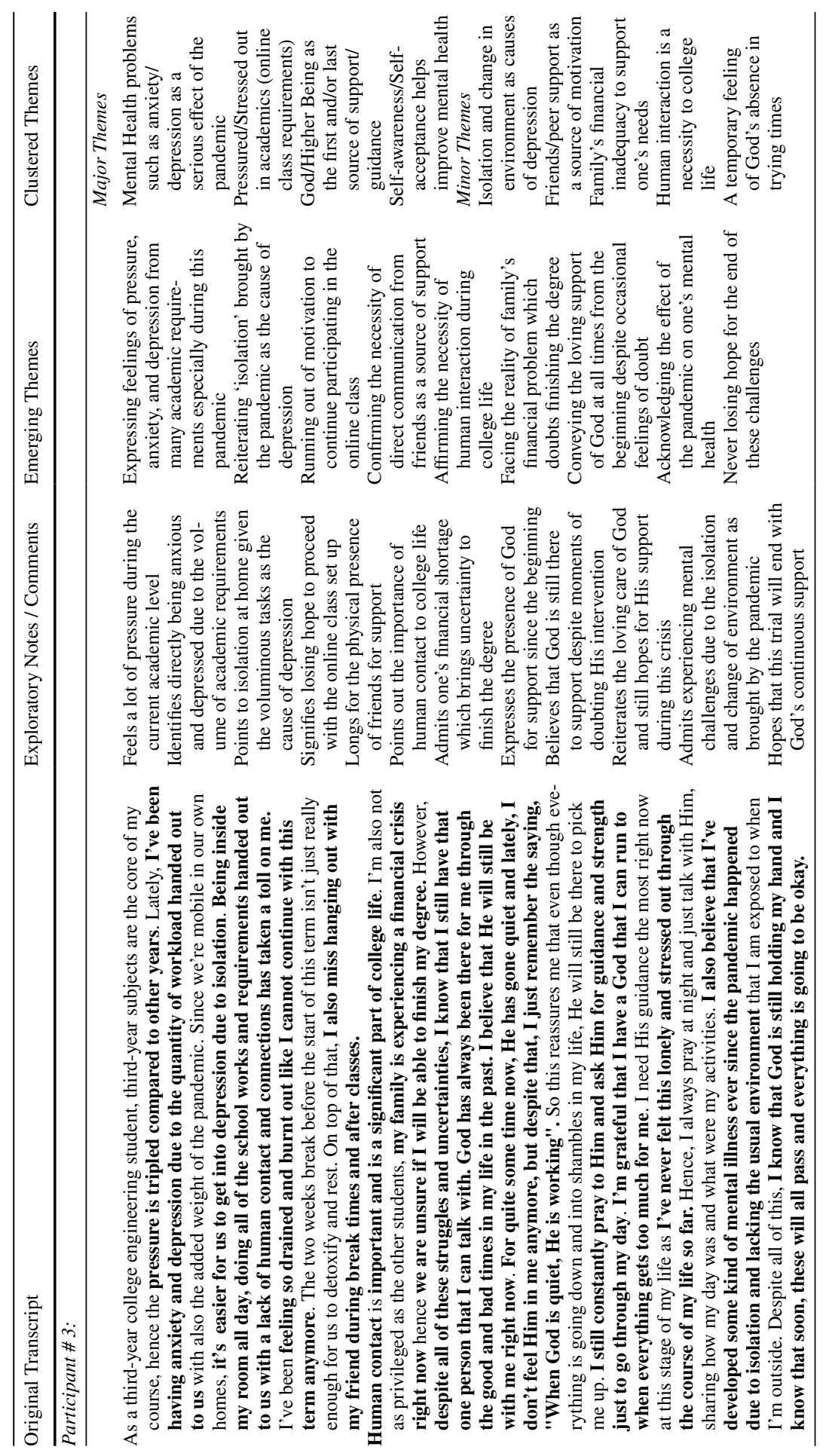




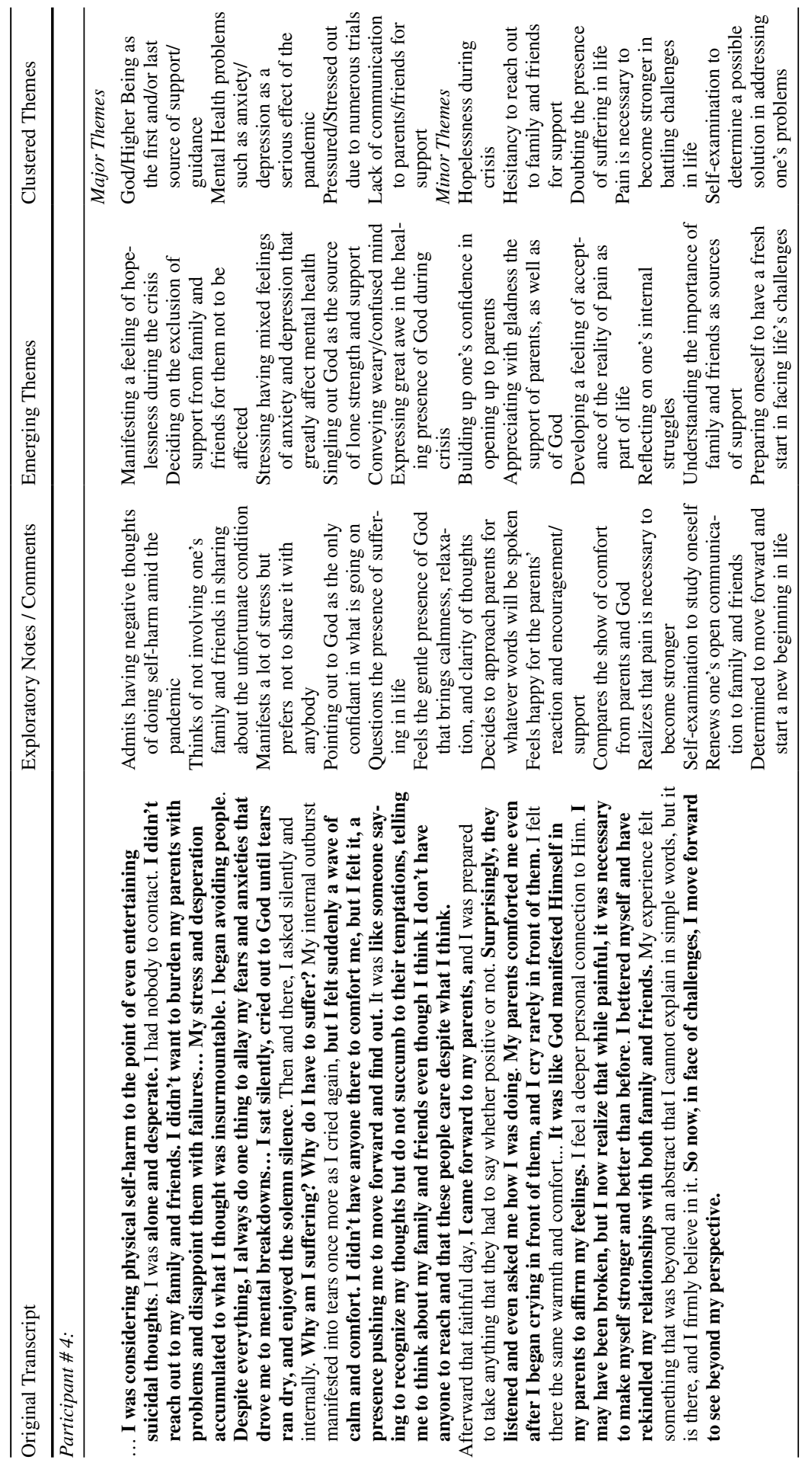




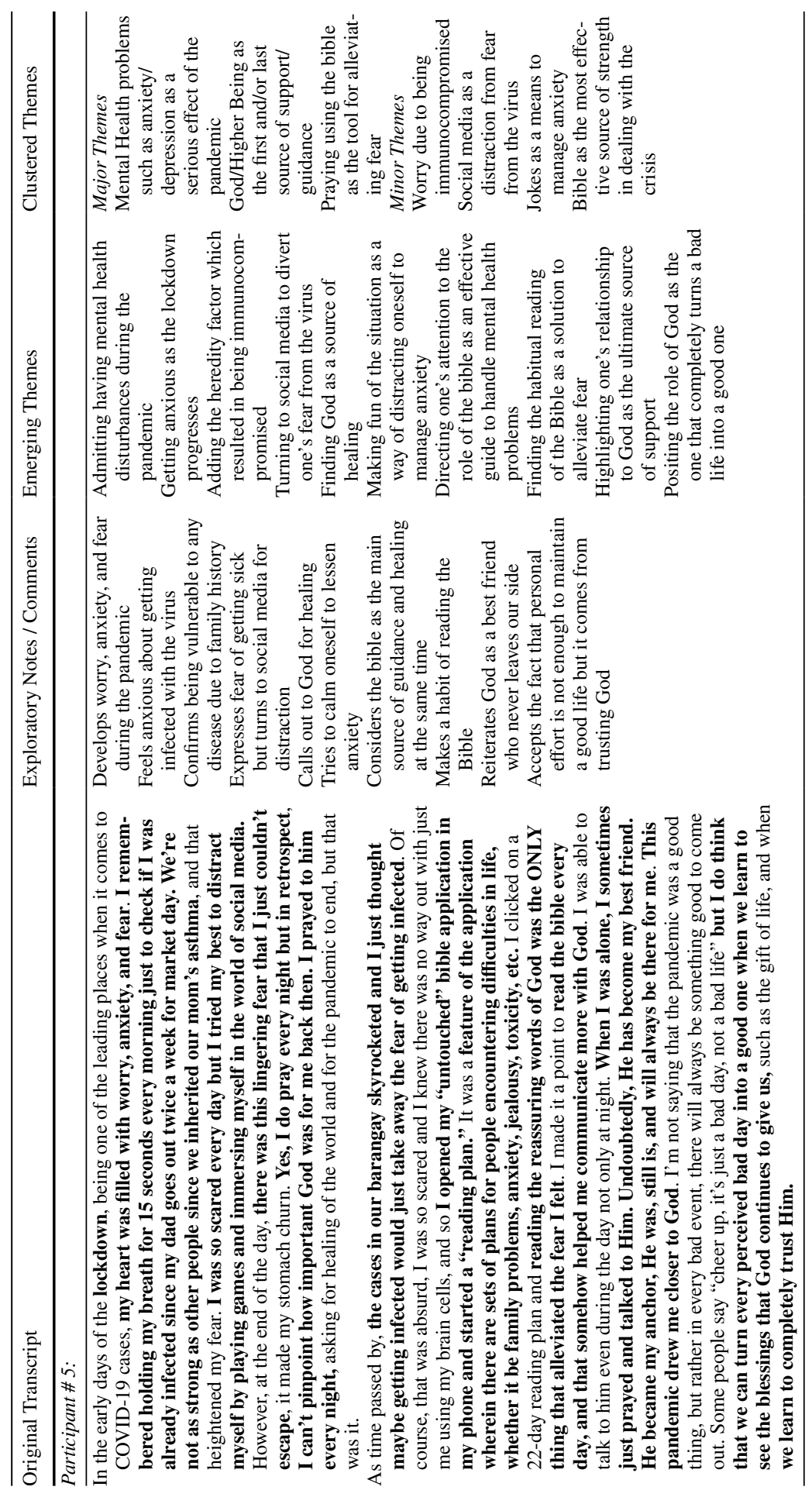




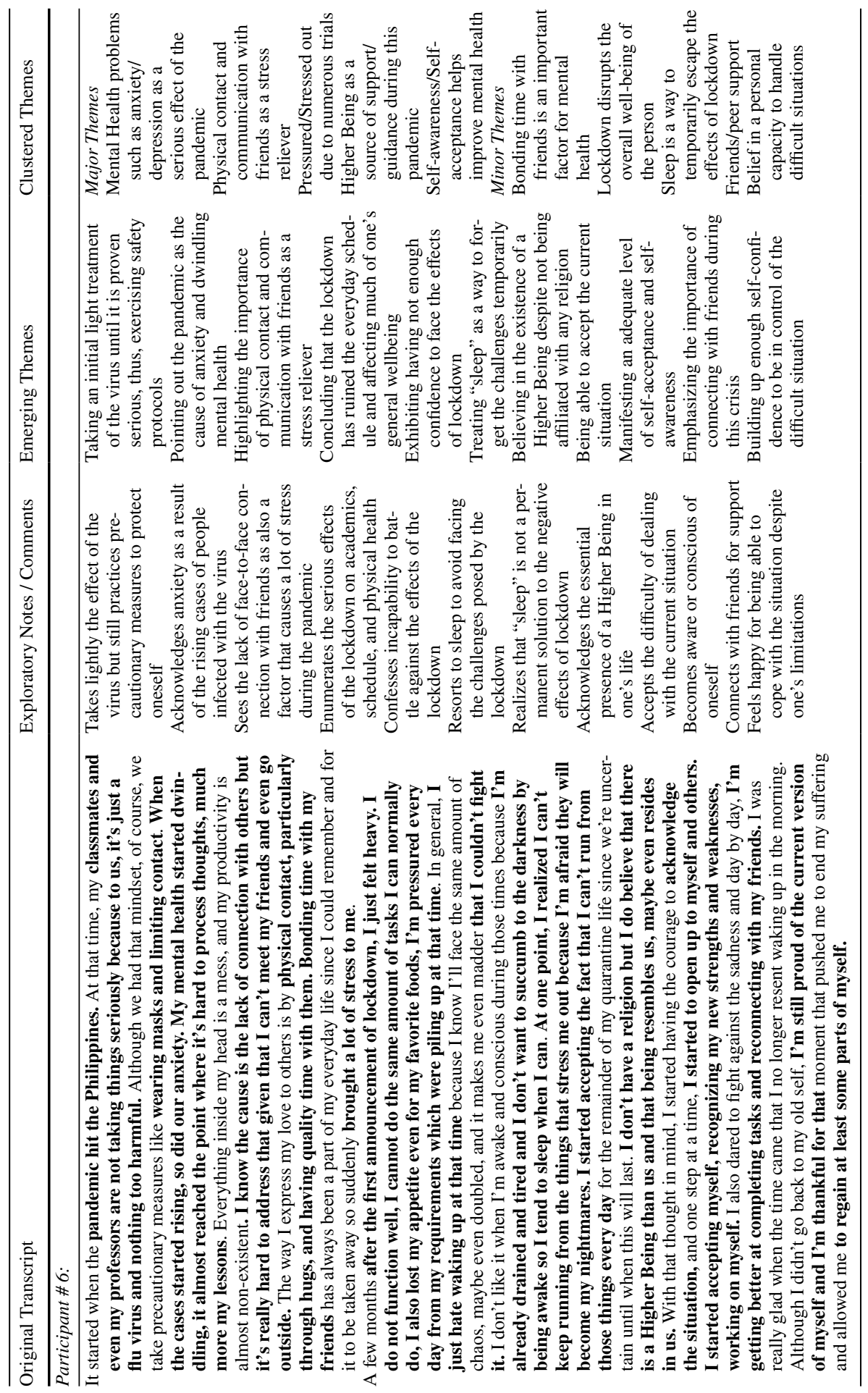


Acknowledgements The author acknowledges all the participants for their very thoughtful sharing of personal perspectives and experiences during the COVID-19 pandemic. This research is also dedicated to all who are undergoing mental health challenges as caused by the crisis.

Funding This study received no funding outside of the author's expense.

\section{Declarations}

Conflict of interest The author declares that he has no conflict of interest.

Animal and Human Rights No animals were involved in this study.

Informed Consent Informed consent was obtained from all individual participants included in the study. Specific permission has been granted to the authors to publish details of anonymous personal reflection papers.

\section{References}

Ackerman, C. (2021). What is self-awareness and why is it important? [+5 Ways to Increase It]. Positive Psychology. Retrieved April 8, from https://positivepsychology.com/ self- awareness-matters-how-you-can-be-more-self-aware/.

Affordable Colleges Online. (2021). Social support for college students success. Affordable Colleges Online. Retrieved May 5, from https://www.affordablecollegesonline.org/college- resource-center/ social-support- campus/.

Alase, A. (2017). The interpretative phenomenological analysis (IPA): A guide to a good qualitative research approach. International Journal of Education and Literacy Studies, 5(2), 9-19. https://doi. org/10.7575/aiac.ijels.v.5n.2p.9

American Psychological Association. (2020). Faith in a time of crisis. Retrieved May 11, from https:// www.apa.org/topics/covid-19/faith-crisis.

American Psychiatric Association. (2000). Diagnostic and statistical manual of mental disorders (4th ed.). American Psychiatric Press.

Antony, M., \& Barlow, D. (1996). Emotion theory as a framework for explaining panic attacks and panic disorder. In R. M. Rapee (Ed.), Current Controversies in the Anxiety Disorder (pp. 55-76). Kluwer Academic/Plenum.

Ashley, G., \& Reiter-Palmon, R. (2012). Self-awareness and the evolution of leaders: The need for a better measure of self-awareness. Psychology Faculty Publications. Retrieved June 5, from https://digit alcommons.unomaha.edu/psychfacpub/7.

Banerjee B., \& Fields, G. (2020). Virus lockdown changes how Hindus celebrate holy period. Retrieved April 2, from https://cbs6albany.com/news/coronavirus/virus-lockdown-chang es- how-hindus-celebrate-holy-period.

Bernard, M. (2020). Self-acceptance: The foundation of mental health and wellbeing. Retrieved November 11, from https://www.youcandoiteducation.com.au/wp- content/uploads/2019/11/Self-Acceptance-TheFoundation-Mental-Health-Wellbeing.pdf.

Biswas, S., \& Biswas, A. (2021). Anxiety level among students of different college and universities in India during lock down in connection to the COVID-19 pandemic. Journal of Public Health: From Theory to Practice. https://doi.org/10.1007/s10389-020-01431-8

Cao, W., Fang, Z., Hou, G., Han, M., Xu, X., Dong, J., \& Zheng, J. (2020). The psychological impact of the COVID-19 epidemic on college students in China. Psychiatry Research, 287, 112934. https:// doi.org/10.1016/j.psychres.2020.112934

Cordero, D., Jr. (2021a). Sákit Pighati and Pag-asa: A Pastoral Reflection on Suffering during the COVID-19 Pandemic in the Philippines. Journal of Religion and Health, 60, 1521-1542. https:// doi.org/10.1007/s10943-021-01234-5 
Cordero, D., Jr. (2021). Theological reflection on suffering: overcoming anxiety and depression during the COVID-19 pandemic. Theology Today, 78(1), 8-12. https://doi.org/10.1177/2F0040573621100 4865

Cordero, D., Jr. (2021c). To stop or not to stop 'culture': Determining the essential behavior of the government, church and public in fighting against COVID-19. Journal of Public Health, 43(2), e309e310. https://doi.org/10.1093/pubmed/fdab026

Coyle, D. (2014). Phenomenology. In A. McIntosh-Scott, T. Mason, E. Mason-Whitehead, \& D. Coyle (Eds.), Key Concepts in Nursing and Healthcare Research (pp. 116-124). Sage.

Dein, S., Loewenthal, K., Lewis, C., \& Pargament, K. (2020). COVID-19, mental health and religion: An agenda for future research. Mental Health, Religion and Culture, 23(1), 1-9. https://doi.org/10. 1080/13674676.2020.1768725

Del Castillo, F., Biana, H., \& Joaquin, J. (2020). ChurchInAction: The role of religious interventions in times of COVID-19. Journal of Public Health, 42(3), 633-634. https://doi.org/10.1093/pubmed/ fdaa086

Eisenberg, D., Lipson, S., \& Heinze, J. (2020). The healthy minds study: Fall 2020 data report. Retrieved March 15, from https://healthymindsnetwork.org/wp- content/uploads/2021/02/HMS-Fall-2020National-Data-Report.pdf.

Eurich, T. (2018). What self-awareness really is (and How to Cultivate it). Retrieved January 4, from https://hbr.org/2018/01/what-self-awareness-really-is-and-how-to-cultivate-it.

Fava, M., Rankin, M., Wright, E., Alpert, J., Nierenberg, A., Pava, J., \& Rosenbaum, J. (2000). Anxiety disorders in major depression. Comprehensive Psychiatry, 41(2), 97-102. https://doi.org/10.1016/ s0010-440x(00)90140-8

Guillasper, J., Oducado, R., \& Soriano, G. (2021). Protective role of resilience on COVID-19 impact on the quality of life of nursing students in the Philippines. Belitung Nursing Journal, 7(1), 43-49. https://doi.org/10.33546/bnj.1297

Heilweil, R. (2020). This social network for churches is thriving in the coronavirus pandemic. Retrieved March 27, from https://www.vox.com/recode/2020/3/27/21194239/coron avirus- churches-online-pray-com.

Islam, M., Barna, S., Raihan, H., Khan, M., \& Hossain, M. (2020). Depression and anxiety among university students during the COVID-19 pandemic in Bangladesh: A web-based cross- sectional survey. PLoS ONE, 15(8), e0238162. https://doi.org/10.1371/journal.pone.0238162

Kalin, N. (2020). The critical relationship between anxiety and depression. The American Journal of Psychiatry, 177(5), 365-367. https://doi.org/10.1176/appi.ajp.2020.20030305

Kessler, R., \& Wang, P. (2008). The descriptive epidemiology of commonly occurring mental disorders in the United States. Annual Review of Public Health, 29, 115-129. https://doi.org/10.1146/annurev. publhealth.29.020907.090847

Kreibich, A., Hennecke, M., Brandstätter, V., \& Wrzus, C. (2020). The effect of self-awareness on the identification of goal-related obstacles. European Journal of Personality, 34(2), 215-233. https:// doi.org/10.1002/2Fper.2234

Labrague, L., \& Ballad, C. (2020). Lockdown fatigue among college students during the COVID-19 Pandemic: Predictive role of personal resilience, coping behaviours, and health. medRxiv. https://doi. org/10.1101/2020.10.18.20213942

Lischer, S., Safi, N., \& Dickson, C. (2021). Remote learning and students' mental health during the Covid19 pandemic: A mixed-method enquiry. Prospects. https://doi.org/10.1007/s11125-020-09530-w

Madhav, K., Sherchand, S., \& Sherchan, S. (2017). Association between screen time and depression among US adults. Preventive Medicine Reports, 8, 67-71. https://doi.org/10.1016/2Fj.pmedr.2017. 08.005

Michigan Medicine. (2021). Coping with the COVID-19 Pandemic as a College Student. Retrieved March 29, from https://medicine.umich.edu/dept/psychiatry/michigan-psychiatry-resources- covid-19/ adults-specific-resources/coping-covid-19-pandemic-college-student.

Active Minds. (2020). COVID-19 Impact on college student mental health. Retrieved March 27, from https://www.activeminds.org/wp-content/uploads/2020/04/Student-Survey- Infographic.pdf.

Odriozola-González, P., Planchuelo-Gómez, Á., Irurtia, M., \& de Luis-García, R. (2020). Psychological effects of the COVID-19 outbreak and lockdown among students and workers of a Spanish university. Psychiatry Research, 290, 113108. https://doi.org/10.1016/j.psychres.2020.113108

Pietkiewicz, I., \& Smith, J. (2014). A practical guide to using interpretative phenomenological analysis in qualitative research psychology. Psychological Journal, 20(1), 7-14. https://doi.org/10.14691/cppj. 20.1 .7 
Rehman, U., Shahnawaz, M., Khan, N., Kharshiing, K., Khursheed, M., Gupta, K., Kashyap, D., \& Uniyal, R. (2020). Depression, anxiety and stress among Indians in times of COVID-19 lockdown. Community Mental Health Journal, 57, 42-48. https://doi.org/10.1007/s10597-020-00664-x

Reznik, A., Gritsenko, V., Konstantinov, V., Khamenka, N., \& Isralowitz, R. (2020). COVID-19 fear in Eastern Europe: Validation of the fear of COVID-19 scale. International Journal of Mental Health and Addiction. https://doi.org/10.1007/s11469-020-00283-3

Robinson, K. (2020). How are major religions responding to the coronavirus? Retrieved March 19, from https://www.cfr.org/in-brief/how-are-major-religions-responding-coronavirus.

Salguero, P. (2020). How do buddhists handle coronavirus? The answer is not just meditation. Retrieved May 15, from https://theconversation.com/how-do-buddhists-handle-coron avirus- the-answer-is-not-just-meditation-137966.

Singh, S., Roy, M., Sinha, K., Parveen, S., Sharma, G., \& Joshi, G. (2020). Impact of COVID-19 and lockdown on mental health of children and adolescents: A narrative review with recommendations. Psychiatry Research. https://doi.org/10.1016/j.psychres.2020.113429

Smith, J., \& Osborn, M. (2015). Interpretative phenomenological analysis as a useful methodology for research on the lived experience of pain. British Journal of Pain, 9, 41-42. https://doi.org/10.1177/ 2049463714541642.

Son, C., Hegde, S., Smith, A., Wang, X., \& Sasangohar, F. (2020). Effects of COVID-19 on college students' mental health in the United States: Interview survey study. Journal of Medical Internet Research, 22(9), e21279. https://doi.org/10.2196/21279

Sutton, A. (2016). Measuring the effects of self-awareness: Construction of the self-awareness outcomes questionnaire. Europe's Journal of Psychology, 12(4), 645-658. https://doi.org/10.5964/ejop.v12i4. 1178

Tee, M., Tee, C., Anlacan, J., Aligam, K., Reyes, P., Kuruchittham, V., \& Ho, R. (2020). Psychological impact of COVID-19 pandemic in the Philippines. Journal of Affective Disorders, 277, 379-391. https://doi.org/10.1016/j.jad.2020.08.043

Twenge, J., \& Campbell, W. (2018). Associations between screen time and lower psychological wellbeing among children and adolescents: Evidence from a population- based study. Preventive Medicine Reports, 12, 271-283. https://doi.org/10.1016/j.pmedr.2018.10.003

Unger, K. (2007). Handbook on Supported Education: Providing Services for Students with Psychiatric Disabilities. BookSurge Publishing.

Wang, C., Tee, M., Tee, C., Pan, R., Reyes, P., Wan, X., Anlacan, J., Tan, Y., Xu, L., Harijanto, C., Kuruchittham, V., Ho, C., \& Ho, R. (2020). Impact of the COVID-19 pandemic on physical and mental health in lower and upper middle-income Asian Countries: A comparison between the Philippines and China. Frontiers in Psychiatry, 11, 1-15. https://doi.org/10.3389/fpsyt.2020.568929

Publisher's Note Springer Nature remains neutral with regard to jurisdictional claims in published maps and institutional affiliations. 